\title{
THE NATIONALIZATION OF BASIC INDUSTRIES IN GREAT BRITAIN
}

\author{
CIIVE M. SCHMITTHOFF* \\ I \\ INTRODUCTION
}

On March 2r, I943, the Prime Minister of Britain, Mr. Winston S. Churchill, broadcast a fireside talk to the nation. He spoke of Britain's post-war aims, and while making it clear that in his opinion a revival of "healthy and vigorous private enterprise" at the earliest moment was vital for that purpose, said ${ }^{1}$ that it was necessary

to make sure that we have projects for the future employment of the people and the forward movement of our industries carefully foreseen, and, secondly, that private enterprise and state enterprise are both able to play their parts to the utmost.

A number of measures are being and will be prepared which will enable the government to exercise a balancing influence upon developments which can be turned on or off as circumstances require. There is a broadening field for state ownership and enterprise, especially in relation to monopolies of all kinds.

Lord Beveridge commented on that speech as follows: ${ }^{2}$

In dealing with the last of these evils-unemployment-the Prime Minister uses more than once a phrase which must have made the Quintilians of individualism stare and gasp: "State enterprise." By this phrase he recognizes that industry conducted by the state, that is to say, not subject to the test and motive of profit, may be enterprising. In his project of making "State enterprise and free enterprise both serve national interests and pull the national wagon side by side," he places on record a hope that the way to the practical end of ordered opportunity for all will be found along a middle course between conflicting ideologies.

These statements accurately describe the spirit in which the British people, after the second world war, began the Great Experiment of charting a "middle course between conflicting ideologies" by nationalizing some basic industries and establishing an economic system where "private enterprise and state enterprise are both able to play their parts to the utmost."

Has the Great Experiment succeeded? It is not the purpose of this symposium to answer that question. ${ }^{3}$ Whatever the verdict of history will be, one thing is certain:

*LL.M. University of London; of Gray's Inn, Barrister-at-law. Lecturcr in Legal Studies and Senior Assistant Member of Staff, The City of London College. General Editor, Business Law AND Administration (195I); author, A Textbook of the English Conflict of Laws (2d ed. 1948); The Export Trade (2d ed. 1950); The Sale of Goods (195i).

2 William H. Beveridge, The Pillars of Selcurity 189-19o (1943).

1 The Times, Mar. 22, 1943, pp. 5-6.

${ }^{3}$ Mr. A. de Neuman, infra, p. 715, rightly points out that arguments for and against an affirmative answer can be advanced with equal facility. 
the nationalization of coal, ${ }^{4}$ iron and steel, ${ }^{5}$ electricity ${ }^{6}$ and gas, ${ }^{7}$ transport by rail, road and inland waterways, ${ }^{8}$ civil aviation, ${ }^{9}$ and other economic activities ${ }^{10}$ has altered the traditional pattern of life in Britain and, together with the welfare legislation enacted after the war, ${ }^{11}$ has led to social changes ${ }^{12}$ which might prove to be as radical in their effect as was the emancipation of the villeins in the fourteenth century and the industrial revolution of the eighteenth and nineteenth centuries.

Five years have now passed since the first nationalization acts were placed on the statute book. During that time there has been a steady growth of the law of nationalized industries, an administrative practice has been established in the public corporations, and their relations to the ministries, private industry, the public, and labor have been clarified. This development is overshadowed by the political controversy and has received little attention in legal and other literature. In this symposium it is intended to give a factual account of nationalization at work, to discuss the difficulties which those called upor to carry out the will of Parliament encountered, and to describe how they attempted to solve them. The authors invited to contribute to this symposium have been chosen for their expert knowledge, without regard to the colour of their political conviction; they have been given liberty of expressing whatever views they hold while writing from their particular technical angle. Their survey indicates how new ideas are blended with traditional institutions and how trends leading into the future are emerging.

\section{II}

\section{Historical ANTECEDENTS}

In I937, Professor William A. Robson published his Public Enterprise which has the sub-title Developments in Social Ownership and Control in Great Britain. ${ }^{13}$ The book, a symposium containing contributions by nine authors and edited for the New Fabian Research Bureau, was the first comprehensive work describing the various new public corporations-or as they were called in those days, public boards -which were created in the period between the wars. In the words of Professor Robson, ${ }^{14}$

\footnotetext{
4 Ooal Industry Nationalisation Act, I946, 9 \& Io Gro. 6, c. 59 (as amended).

'Iron and Steel Act, 1949, 12, I3 \& 14 GEO. 6, c. 72.

- Electricity Act, I947, to \& II GEo. 6, c. 54 .

${ }^{7}$ Gas Act, I948, II \& I2 Geo. 6, c. 67.

${ }^{8}$ Transport Act, 1947, I0 \& II Geo. 6, c. 49.

- Civil Aviation Act, 1946,9 \& ro Geo. 6 , c. 70, consolidated with other enactments into the Air Corporations Act, 1949, I2, I3 \& $x_{4}$ GEO. 6, c. 9r, which is the Act in operation at present.

${ }^{10}$ See Professor W. Friedmann, infra, p. 576, and Mr. A. de Neuman, infra, p. 702.

11 National Insurance Act, 1946, 9 \& 10 GEO. 6, c. 67; National Insurance (Industrial Injurics) Act, 1946, 9 \& 10 Geo. 6, c. 62; National Health Service Act, 1946, 9 \& 10 Geo. 6, c. 81.

${ }_{12}$ LoRd JUSTice AlFred T. Denning, Freedom UNDer THE LAw 75 (1949); "The social revolution of today has changed all that. Parliament has put on the State the positive responsibility of secing that everyone is provided with the necessities of life."

13 (London, 1937). See further, Lincoln Gordon, The Public Corporation in Great Brituin (London, 1938), and Friedmann, The New Public Corporations and the Latw, ro Mod. L. REv. 233, 377 (1947).

14 Public Enterprise 359 (Robson ed. 1937).
} 
These boards grew up in a typically British fashion. They were not based on any clearly defined principle; they evolved in a haphazard and empirical manner; and until quite recently very few people were aware of their importance or even of their existence. Now suddenly they have become all the rage. Politicians of every creed, when confronted by an industry or a social service which is giving trouble or failing to operate efficiently, almost invariably propose the establishment of an independent public board.

Professor Robson's work had a profound influence on the development of the public business corporation after the war; on importance it can be compared with The Modern Corporation and Private Property by Berle and Means, ${ }^{15}$ which in the. Thirties greatly influenced the thought of company lawyers on both sides of the Atlantic. Like the latter, Professor Robson's symposium has now become a classic, but it is still a useful starting point for an investigation into modern problems of nationalization.

The authors writing in Professor Robson's symposium review the following enterprises:

(I) The Port of London Authority (Ig08), ${ }^{16}$

(2) The Forestry Commission (I919),

(3) The British Broadcasting Corporation (1926),

(4) The Central Electricity Board and other Electricity Authorities (1926),

(5) The London Passenger Transport Board (1933),

(6) The Coal Mines Reorganisation Commission (1930),

(7) The Agricultural Marketing Boards (193r),

(8) The Post Office,

(9) The organization of the cooperative movement.

It is interesting to compare that list with the principal nationalized industries treated in this symposium, viz.:

(I) The National Coal Board (r946),

(2) The Iron and Steel Corporation (1949),

(3) The British Electricity Authority (1947),

(4) The Gas Council (r948),

(5) The British Transport Commission (I947),

(6) The British Overseas Airways Corporation (1939),

(7) The British European Airways Corporation (1946),

(8) The British Broadcasting Corporation (r926).

Already in 1937, Professor Robson had doubt whether to include in his list the cooperative movement and the Post Office which he described as. "the traditional method of organizing a socialized service"; $;^{17}$ he justified their inclusion by stating that they were added mainly for purposes of comparison. Yet, approaching, as he did, the problem from the angle of social ownership, the inclusion of those two enterprises into his list appears legitimate. In $195 x$, when the emphasis has shifted from

${ }^{16}$ (New York, r932).

10 The years in parenthesis refer to the date when the board was established.

${ }^{17}$ Public ENterprise 9 (Robson ed. I937). 
social ownership and public boards to state ownership and public business corporations, it is evident that those two enterprises are different in character and purpose from the modern type of public corporation. Cooperative societies are, in essence, a form of private enterprise. Moreover, as an eminent cooperative planner admits, ${ }^{18}$ ... within the capitalist competitive system, the co-operative movement is being forced into the position of a capitalist organization to some extent.

Like the joint stock company, the cooperative society is owned by shareholders and guided by the principle of distributable profit, though in the case of the joint stock company the basis of distribution is the shareholding of the members and in that of the cooperative society it is the amount of the members' purchases. Whether the cooperative society represents a form of capitalist or social private enterprise, is irrelevant for our investigation because in any case it is a type of private as opposed to state enterprise. ${ }^{19}$ The Post Office and the Forestry Commission ${ }^{20}$ which appear in Professor Robson's list, are likewise dissimilar to modern nationalized industries. The Post Office is a department of state; its head, the Postmaster-General, is a minister of the Crown. The Forestry Commission, modeled after the Ecclesiastical and Charity Commissions, ${ }^{21}$ was even in 1937 "more directly under parliamentary and Treasury control"22 than the other boards listed by Professor Robson. Both types lack the managerial autonomy characteristic of the modern public business corporation. Further, the Agricultural Marketing Boards ${ }^{\mathbf{2 3}}$ which Professor Robson includes in his list are in a different category from the modern statutory corporations owning and managing nationalized industries; unlike the latter, they do not own the means of production but have merely regulatory functions or act as trading or distributive agencies. Although they may have a trading monopoly, as e.g., the Milk Marketing Board possesses, their purpose is different from that of a nationalized industry because they serve sectional and not national interests, viz., the benefit of those producing the goods marketed by them.

The five boards remaining on Professor Robson's list are of the public service board type which can claim parental relations to the post-war public corporation. Of these, the Port of London Authority which operates under the Port of London (Consolidation) Act, $1920,^{24}$ and the British Broadcasting Corporation which is in-

${ }^{18} \mathrm{G}$. Walworth, The Organization of the Co-operative Movement, in Public ENTERPRIse, id. at 350.

${ }^{29}$ At the meeting of the Cooperative Party at New Brighton on March 25, 1951, much criticism of the nationalized indystries was expressed. The Times, Mar. 26, 1951.

${ }^{30}$ Created by the Forestry Act, I919, 9 \& 10 Geo. 5, c. 58, as amended.

${ }^{21}$ John Parker, The Forestry Commission, in Public EnTERPRIse, op. cit. supra note 13, at 59, 61.

22 Id. at 72 .

${ }^{23}$ Created under the Agricultural Marketing Acts, I93I and I933, 21 \& 22 GEo. 5, c. 42; 23 \& 24 Geo. 5, c. $3 I$, and further the Agricultural Marketing Act, $1949,12 \& 13$ GEo. 6, c. 38 . Under these Acts, schemes are operated for the marketing of milk, hops, pigs and bacon, and potatoes, tomatocs and cucumbers, and British wool.

${ }^{24}$ yo \& i i Geo. 5, c. I73, as amended. See Hubert Le Mesurier, The Law Relating to the Port of LoNDON AutHority (1934). 
corporated by royal charter, ${ }^{25}$ are still in existence and operate nowadays under virtually the same constitution as in I937. The Central Electricity Board, the Coal Mines Reorganisation Commission, and the London Passenger Transport Board were, as might be said retrospectively, transitional organizations which have been merged into the post-war corporations owning electricity, coal, and transport.

Among the pre-war boards which have an affinity with the post-war corporations two require particular attention, namely the Port of London Authority and the London Passenger Transport Board. Both have an interesting history. The constitution of the Port of London Authority, which nowadays owns and manages the docks and port installations of the largest port of Europe, was modeled after that of the Mersey Docks and Harbour Board which was created in $1857 .^{26}$ On the Mersey a keen competition had arisen between the ancient Liverpool docks, which since the reign of King John were administered by the municipal authorities of Liverpool, and the docks of Birkenhead, which are situated across the river and came into prominence in the first half of the nineteenth century when they were strongly supported by the Great Western Railway and the landowners of Cheshire. ${ }^{27}$ The rivalry of the two dock areas was ended by the creation of the board in which was vested the property in the docks and other port installations on both sides of the river and which "was in addition entrusted with the conservancy of the lower river, the control of pilotage and the lighting and buoying of the harbour."28 The Mersey Docks and Harbour Board, which is still in existence, is the first great public business corporation in Britain. The success of that Board greatly influenced the reorganization of the port of London at the beginning of the twentieth century. ${ }^{29}$ In London wharves and docks were owned by joint stock companies which were unable or unwilling to modernize the dock installations in accordance with the requirements of the increasing trade of the port. In addition, the conservancy of the river Thames, which was under the control of public authorities, was inadequate. The great continental ports, in particular Hamburg, Antwerp, and Rotterdam, began to compete seriously with London, especially in the transit trade. Mainly as the result of Mr. Lloyd George's initiative, when he was president of the Board of Trade, the Port of London Authority was established by Act of Parliament in 1908. ${ }^{30}$ Again, the property in the wharves, docks, and other port installations was vested in a statutory body which

${ }^{25}$ The first charter was granted on January $\mathrm{r}, \mathrm{x} 927$ and limited to ten years. The second charter, granted on January 1,1937 , was likewise for ten years; the third charter, of January 1, 1947, which was limited to five years, is at present under review; the government proposes a charter for I5 years and a quinquennial review of the working of the Corporation (CMD. No. 829r.) On the changes in the constitutional provisions of the charters and consequential agreements, see D. N. ChEster, The NationaIISED INDUStries; A Statutory ANalysis 86 et seq. (London, 2d ed. I95I).

${ }^{28}$ By the Mersey Docks and Harbour Act, I857, 20 \& 21 VicT., c. CLXII.

${ }^{27}$ Dr. Lincoln Gordon, The Port of London Authority, in Public Enterprise, op. cit, stpra note I3, at 13, 14. The historical account of the Mersey Docks and Harbour Board and the Port of Iondon Authority in the text is based on Dr. Gordon's article.

${ }^{38} I d$. at $15-16$.

${ }^{20} \mathrm{Id}$. at $16-17$.

${ }^{30}$ By the Port of London Act, 1908, 8 EDw. 7, c. 68; for the Act in force at present, see note 24 stupra. 
was charged with the management of the port and the conservancy of the river. ${ }^{31}$ The board consists of 28 members, I8 being elected by the "consumers" and Io appointed by central or local authorities. Of the 18 elected members, 8 are nominated by the shipowners, 8 by the merchants, one by the rivercraft owners, ${ }^{32}$ and one place goes to the wharfingers. The chairman of the Authority and the vice-chairman may be appointed from the outside and the membership of the board thereby be increased to 30. The present chairman of the Authority is Sir John Anderson. Here again, the establishment of the public board proved to be successful. In the post-war period, the Port of London, like other ports in the United Kingdom, encountered difficulties, particularly with respect to unofficial strikes ${ }^{32 a}$ and the turn-round of ships which was slower than was desirable, ${ }^{33}$ but these difficulties were not connected with the constitution or organization of the Port Authority.

The other pre-war board which greatly influenced the post-war development was the London Passenger Transport Board. When examining its antecedents, one is tempted to refer to the old French rule that la recherche de la paternité est enterdite, because, in the words of Professor Robson ${ }^{34}$ the bill

was introduced into Parliament by a Labour Minister, continued by his Liberal successor in office, and piloted through its final stages by a Conservative Minister of Transport.

However, although the passing of the bill was due to the combined efforts of all political parties in Great Britain, the credit for the measure must undoubtedly go to Mr. Herbert Morrison. "To him can be traced not only the eventual creation of the [London Passenger Transport Board] but also the particular type of public corporation which emerged."35 Already before the passing of the London Passenger Transport Act, $1933{ }^{38}$ the uncoordinated growth of the London transport system was gradually reduced by an amalgamation and combination of underground and omnibus companies between 1907 and I9I3 which resulted in 1924 in the emergence of a combine controlled by Lord Ashfield and owning the bulk of London's transport services. But the continued expansion and the call for better transport facilities which could only be obtained by considerable capital expenditure required more resolute measures. In these circumstances Mr. Herbert Morrison proposed the creation of the London Passenger Transport Board which became ${ }^{37}$

\footnotetext{
${ }^{31}$ But certain public functions are exercised by the City of London Corporations such as, c.g., the health and sanitary authority in the Port of London; see Cory (William) and Son, Ltd. v. City of London Corporation, [r95 I] I K. B. 8; aff'd, [r95I] 2 All E. R. 85 (C.A.).

${ }^{32}$ Method of Election of Elected Members of the PORT of London Authority; Regulations of THE Minister of TRANSPORT, S. R. \& O., 1930, No. 332.

${ }^{32 a}$ See the London Dock Labor Report (Leggett Report) (H.M.S.O., May i8, 1951).

${ }^{33}$ See Report of the Working Party on the TuRn-Round of Shipping in the United Kingdom Ports, Report to the Minister of Transport (1948).

34 Public Enterprise, op. cit. stipra note 13, at 359. The Ministers referred to by Professor Robson were: Mr. Herbert Morrison, Sir Percy John Pybus, the Honorable Oliver Stanley.

${ }^{35}$ Ernest Davies, The London Passenger Transport Board, in Public Enterprise op. cit. stlpra note 13. at 155,156 . The historical account of the Board in the text is based on Mr. Ernest Davies' article.

${ }_{38}^{23} \& 24$ GEo. 5, c. I4.

${ }^{37}$ Davies, supra note 35 , at 155 .
} 
the accepted model of the Labour Party and the trade unions for the organization of socialized industry.

On the appointed day, viz., July I, I933, the tubes, suburban railways, ${ }^{38}$ busses, coaches, and trams of the companies and local authorities concerned vested in the Board, which issued five classes of stock as compensation for the transfer or acquisition of the undertakings. Of great interest is the procedure for the appointment of the members of the Board. In the original, socialist, bill it was provided that the members should be appointed by the Minister of Transport. This proposal was dropped by the National Government which eventually carried the bill through Parliament because it was feared that that arrangement might involve "the risk of political interference in constituting a business body." ${ }^{39}$ The appointment of members of the Board was entrusted to "Appointing Trustees" who consisted of the heads of local government and professional bodies such as the London County Council, the Law Society, the Institute of Chartered Accountants, and the Committee of London Clearing Bankers, and further the chairman of the Board itself. The first chairman of the London Passenger Transport Board was Lord Ashfield, who held office until 1947. The Board operated the London transport system from July I, I933, to January I, I948 when the Transport Act, I947, came into force, under which the undertakings of the Board vested in the British Transport Commission and the Board after a transitional period will have to be dissolved; ${ }^{40}$ but the former activities of the Board are carried on by a separate Executive of the Commission, the London Transport Executive, which is an agent of the Commission. ${ }^{41}$ The Transport Act, I947 has thus nationalized undertakings not only of private enterprise and municipal authorities, but also of a nationalized industry.

When comparing the two types of pre-war boards which had a decisive influence on the post-war development, the following points emerge. First, in the early days the constitution of the board was greatly influenced by the conception of trust which likewise had a considerable influence on early English company law, particularly between I825 and I862. ${ }^{42}$ The Mersey Docks and Harbour Board and the Port of London Authority are conceived as public trusts though the property owned by the boards was vested in a corporation and not the trustees (the members of the board). Later the conception of public trust gave way to that of a business body; this change, already reflected in the constitution of the London Passenger Transport Board, was accelerated after the war. Secondly, the pre-war public boards were completely autonomous-the controlling interest in them was not in the hands of

${ }^{34}$ With the exception of those owned by the four Railway Companies (S. R.; G. W. R.; L. \&. N. E. R.; L. M. S.) which remained in private ownership until the coming into operation of the Transport Act, 1947.

${ }^{30}$ Statement as to Certain Modifications Which It Is Proposed to Make in the London Passenger Transport Bill, I931-I932. Cidd. No. 4133 (1932).

Transport Act, 1947, \$24.

11 Id. §I5.

${ }^{42}$ In 1825 the Bubble Act, 1719 , was repealed and in 1862 the first great Companies Act (25 \& 26 Vict., c. 89) admitting the incorporation of companies by registration was passed. 
the government, but in those of the consumers. The latter exercise a direct control in the Port of London Authority: their representatives, the elected members, can outvote the appointed members. In the London Passenger Transport Board, the constitution of Appointing Trustees was intended to provide for indirect representation of the consumers who were too large a class to elect the members of the Board directly. ${ }^{43}$ Thirdly, the operations of the two pre-war boards were on a regional and not a national scale.

\section{III}

\section{Main Features of Nationalization}

\section{A.}

State control of industry might be supervisory, regulatory, or proprietary. Supervisory control is normally exercised by the requirement of licenses, as is the case in England with respect to public houses, theatres, building, exports and imports, and many other instances of industrial and commercial activity; where state interference is limited to supervision, the ownership in the undertakings concerned is in private hands and those controlling them have considerable freedom in their management. Regulatory control is exercised, e.g., in the United States of America over public utility enterprises ${ }^{44}$ and in the United Kingdom by means of price control; here the ownership in the undertakings remains in the hands of private entrepreneurs but their discretion of management is considerably restricted by government regulation. Proprietary control is the strictest type of control which the state can exercise; under this system the ownership in the undertakings affected is vested in the state or statutory bodies which are charged with the management of them in the national interest and exercise the full control normally associated with the conception of ownership. The nationalized industries in Great Britain fall within the third category but the strictness of proprietary control is mitigated by the transfer of ownership in the nationalized industries to a new form of industrial organization of very peculiar character, viz., the quasi-autonomous public corporation.

In every instance in which an industry formerly owned by private enterprise was transferred to public ownership, the procedure by which the transfer was effected was a vesting provision in the nationalization act which provided that on the appointed day certain assets should vest in the corporation created by the $\mathrm{act}^{45}-\mathrm{a}$ provision which resulted in the consequential divesting of the former owners. A typical provision of this kind is Section I2 of the Transport Act, 1947, which deals

\footnotetext{
${ }^{3}$ Chester, The Nationalised Industries, op. cit. supra note 25 , at 5 (Ist ed.), observes that the ministerial control over the P. L. A. is stricter than over the L. P. T. B.

"4. C. Bonbright, Public Utilities and the National Power Policies (1940).

"E In the case of the Bank of England and Cable and Wireless, Ltd., in nominees of the Treasury. Bank of England Act, x946, 9 \& to Geo. 6, c. 27, 1 (1)(a); Cable and Wireless Act, 1946, 9 \& 10 Geo. 6, c. $82, \S I(I)(a)$.
} 
with the acquisition of railway and canal undertakings by the British Transport Commission. It states:

I2. Vesting of undertakings. (I) Subject to the provisions of this Act, the whole of the undertakings of the bodies of persons specified in the Third Schedule to this Act, being the bodies who fall within the class described in the next succeeding section, shall, on the first day of January, nineteen hundred and forty-eight (hereafter in this Part of this Act, and in the other provisions of this Act so far as they refer to the acquisition by the Commission of the said undertakings, referred to as "the date of transfer"), vest by virtue of this Act in the Commission.

The conveyancing device of vesting by operation of law is familiar in the law of succession, bankruptcy, and trading with the enemy.

As in most cases the assets which under the nationalization act were to vest in the corporations, were, before vesting date, held by companies, the acquisition of those assets could be carried out in two different forms. The vesting provision could provide for the transfer of certain real and personal property owned by the companies, such as coal mines, railway wagons, and gas undertakings, or alternatively, for the acquisition of the shares in those companies. The former is a direct, open method of nationalization, the latter an indirect form. ${ }^{46}$ The direct method was applied to the nationalization of coal, transport, electricity, and gas. The indirect method was used for the transfer to public ownership of iron and steel undertakings, the Bank of England, and Cable and Wireless Ltd. ${ }^{47}$ The distinction between those two methods is considerable. Under the direct method, the compensation which usually consisted of stock issued by the statutory corporation, ${ }^{48}$ took the place of the transferred capital assets of the affected companies which continued their corporate existence ${ }^{49}$ but ceased to be actively engaged in business; they had three courses open: they could go into liquidation, ${ }^{50}$ or continue as investment or finance companies, ${ }^{51}$ or sell the compensation stock and start again in business in a field still open to private enterprise; the decision on the course to be adopted depended on the shareholders. Where the indirect method of nationalization was employed, only the controlling interest changed hands and compensation was directly paid to the shareholders; this method was, in particular, adopted where it was feared that a direct transfer of assets might lead to a disruption of the industrial or commercial activities of the companies.

\footnotetext{
${ }^{10}$ For details, see Professor W. Friedmann, infra, p. 576, and Dr. Mary Bell Cairns, infra, p. 6or. Dr. Cairns has made a detailed study of the various methods of nationalization because, as she rightly observes, the method of compensation varied according to the nationalization procedure employed.

${ }^{17}$ Cairns, infra, pp. 601-602.

${ }^{4} \mathrm{Mr}$. G. F. Wheldon, infra, p. 62\%.

to The Transport Act, 1947, \$24, provides for the winding-up and eventual dissolution of railway and canal undertakings.

${ }^{50}$ Scottish Insurance Corporation v. Wilsons and Clyde Coal Co., Ltd., [1949] A.C. 462; Prudential Assurance Co. v. Chatterley-Whitfield Collieries, [1949] A.C. 5r2; Re Isle of Thanet Electric Supply Co., [I949] 2 All E. R. 1060 (C.A.).

"1 As did the Cable and Wireless (Holding) Ltd.
} 
In Great Britain, nationalization was normally carried out by the direct method of vesting; the indirect method was only employed where special conditions prevailed.

B.

A second feature of British nationalization legislation is its axiomatic insistence on the principle that compensation must be paid for assets transferred from private to national ownership. The importance of this feature cannot be overrated. Dr. Mary Bell Cairns, who examines the problems arising in connection with the assessment and distribution of compensation, rightly points out that the right to compensation is founded on old, established, constitutional practice and concludes that "the principle of compensation for the expropriation of property is an integral part of the English legal and political system."

The right to compensation is one of the features which distinguish the nationalization of basic industries in Britain from the expropriation of property carried out in communist countries. Another distinguishing feature is the place allocated to state enterprise in the fabric of the national economy; while communist countries have established an all-embracing system of state economy, and private ownership, if admitted at all, is admitted only by sufferance and occupies a subordinate place in the national economy, in Britain the system of private ownership is fully maintained and developed and the corporations owning and managing nationalized industries are integrated into that system as a kind of super-companies. A third distinction is that in communist countries the expropriation of the means of production and distribution is a tenet of Marxist doctrine while the nationalization legislation in Britain is, on the whole, more liberal than socialist in outlook and has been rightly described as follows: ${ }^{53}$

The post-war 1945 nationalization acts in Great Britain cannot be regarded unequivocally as milestones on the road to a socialist new Jerusalem. They are in fact compounded of an odd mixture of socialist theory, liberal expediency and political empiricism.

The distinction between nationalization with compensation and expropriation or confiscation without it is recognized by the English courts, as a comparison of Re Baku Consolidated Oilfields, Ltd. ${ }^{54}$ and Re Eastern Telegraph Co., Ltd. ${ }^{55}$ shows. In the former case a winding-up petition was presented in 1943 by shareholders of an English company which before I919 had acquired oilfields in or near Baku but could not obtain title to them because they were confiscated by the Soviet authorities. The company had considerable assets in England which upon winding-up would have become divisible among the shareholders. Bennett, J., who granted the petition, said in the course of his judgment: ${ }^{56}$

\footnotetext{
E2 Cairns, infra, pp. 594 and 6rg.

${ }^{53}$ Beacham, Nationalization in Theory and Practice, 64 Q. J. Ecos. 557 (1950).

[1944] I All E. R. 24 (Ch. D.).

Es [1947] 2 All E. R. IO4 (Ch. D.).

${ }^{68} \mathrm{Re}$ Baku Consolidated Oilfields, Ltd., supra note 54 , at 25 .
} 
It seems pretty clear that, in no true sense of the word did the Baku Consolidated Oilfields, Ltd., carry on any business at all. It had been engaged since I920 in an endeavour to substantiate a claim against the U.S.S.R. Government for loss by confiscation of the properties it was formed to acquire, and for which it has paid. . . It is clear from the evidence that the directors of the company no longer expect their claims to be met by sums coming from Russia.

In Re Eastern Telegraph Co., Ltd., the company owned a considerable portion of shares in the Cable and Wireless Ltd. which, by virtue of the Act of I946, vested on November 6 , 1946 in nominees of the Treasury. Before compensation was paid, preference shareholders petitioned for a winding-up order, relying, inter alia, on the $B a k u$ case. Jenkins, J., refused the order. He distinguished the $B a k u$ case in fact and law and held that as long as the compensation was not assessed and fixed, the petition was premature. He said: $:^{57}$

That transaction is not yet complete. The compensation has to be assessed and received. The amount of compensation is a matter of great importance, and it is obviously desirable in everybody's interests-both in the interests of the preference stockholders and of the ordinary stockholders-that the company's case as to the amount of compensation should be cogently and effectively put in order that the compensation received may be as large as possible. It seems to me that the proper people to look after that matter are the directors of the company ... It would be wrong at this juncture to make a compulsory order which would have the effect of removing them from office, and which would bring in a liquidator who, capable and expert as he might be, would not have the same knowledge as the directors have.

Apart from the right to compensation, there is another fundamental distinction between nationalization and expropriation. The latter usually contains a discriminatory element which is absent from the former. In Great Britain, no discrimination has been practiced on account of the nationality, domicile, or other personal criteria of the companies or persons owning the assets acquired by the state. The test of nationalization was in the words of Mr. Herbert Morrison, then Lord President of the Council, 58

whether, in the circumstances, the industry was likely to be better run by free competitive competition, private enterprise, or free monopoly private enterprise, or controlled and supervised monopoly enterprise, or by public enterprise of one sort or another. It was the public interest that counted and the real field for argument was how best could the industry be organised or managed with a view to achieving economic public advantage.

C.

Perhaps the most important feature of British nationalization legislation is that it has given rise to a new form of business organization, the public business corporation. Professor W. Friedmann who investigates the "Legal Status and Organization of the Public Corporation,"59 divides the public corporation into three classes: the

${ }^{67}$ Re Eastern Telegraph Co., Ltd., supra note 55, at III.

${ }^{68}$ Address to the Board of Trade of the City of Toronto, The Times, Jan. I I, 1946, p. 3.

${ }^{50}$ Infra, p. 576 . 
commercial public corporation, the social service corporation, and the supervisory corporation. The emergence of the first named type and its separation from the other two types of public corporations is one of the most significant developments in the law of business administration in post-war Britain.

From the legal point of view, the crucial event in that development was the decision of the Court of Appeal in Tamlin v. Hannaford, ${ }^{60}$ where it was held that the public business corporation was neither a government department nor an agent of the crown but ${ }^{602}$ "a commercial corporation ... that ... acts on its own behalf, even though it is controlled by a government department," and that, consequently, it was not entitled to the immunities and privileges of the Crown. The beneficial effect on English law of this great decision will be gathered from Professor W. Friedmann's comparison of the judgment with Australian decisions.

The outstanding characteristic of the public business corporation is its quasiautonomous status. While it is a legal entity which pursues industrial and commercial objects in the same manner as a public company and enjoys independence in matters of management and administration, it is subject to the direct control of a minister and indirect control of Parliament in matters of policy and its board is invariably appointed by a minister. In that respect the post-war public corporation follows the model of the socialist proposal for the organization of the London Passenger Transport Board and differs from the boards actually created before the war which were fully autonomous.

The peculiar character of the public business corporation is best understood when it is compared with the company. Three aspects require, in that respect, particular attention: the proprietary position; the attitude to the profit motive; and the relation to labor. As regards the first, it should not be thought that the place filled in the company by the body of shareholders is in the public corporation merely a vacuum. The business which the corporation is charged to perform, is the business of the taxpayer who, in the words of Denning, L. J., in Tamlin v. Hannaford, "is the universal guarantor of the corporation." Unlike the shareholders in many public companies, the nation takes a considerable and constant interest in the activities of the corporations. Their business is transacted in the limelight of public opinion; matters which if they affected companies, would hardly be noticed, are fully-and properly-discussed by the press from every political angle as matters of public concern. In a democratic country where freedom of the press and of discussion is preserved, the proprietary interest in the public corporation is thus more powerful than in the private company and, if need be, can assert itself through the Parliamentary institutions.

${ }^{60}$ [1950] I K.B. I8. (C.A. I949); [1949] 2 All E. R. 327 (C.A.). The decision is analyzed by Professor Friedman, infra p. 588, and Mr. Charles Winter, infra, p. 692. See further R. v. South Wales Traffic Licensing Authority; ex parte Ebbw Vale Urban District Council, [195I] I All E. R. 806.

c02 [1950] I K.B. I8, 25; [1949] 2 All E. R. 327, 330.

${ }^{1}$ Id. at 23,2 All E. R. at 328 . 
As regards profits, it is sometimes said that the public corporation does not aim at the making of profit but at the earning of revenue to cover its expenditure. ${ }^{62}$ This view is, it is believed, fallacious. While all nationalization acts establish the principle of "budget-balancing" for public corporations, ${ }^{63}$ none prohibits, or even discourages, the making and accumulating of profits. In fact, from the legal point of view, the distinction between profit and revenue makes little sense in public corporations. Thus, Section 3(4) of the Transport Act, r947, makes it incumbent on the British Transport Commission to levy such fares and other charges

as to secure that the revenue of the Commission is not less than sufficient for making provision for the meeting of charges property chargeable to revenue, taking one year with another.

Section 92 then authorizes the accumulation of a general reserve without any limitation as to the amount but with the direction that it shall only be applied for the purposes of the Commission. Section 93 begins with the following words:

The Commission shall charge to revenue in every year all charges which are proper to be made to revenue, including, in particular, proper allocations to general reserve. . .

It is evident from those provisions that the Commission-and the same applies to the other corporations-is as free as a private entrepreneur to make and accumulate profits. However, unlike the latter, it cannot distribute ${ }^{64}$ them but has to "plough them back" into the enterprise. Apart from that legal distinction there is, however, a considerable difference in the attitude to the profit motive; a private entrepreneur is free to overcharge his consumers, to underpay his labor, or to waste his plant in order to make profit, as long as he keeps within the law and thinks that it is economically justified; in connection with a company, Evershed, M. R., observed ${ }^{65}$ recently that it is

not necessary to require that persons voting for a special resolution should, so to speak, dissociate themselves altogether from the prospect of personal benefit and consider whether the proposal is for the benefit of the company as a going concern.

The attitude of public business corporations to those aspects of profit-making is fundamentally different; the corporations are, so to speak, entrepreneurs with a national conscience.

\footnotetext{
${ }^{03}$ See, e.g., Lord Beveridge's observations, supra note 2.

${ }^{63}$ Sec Mr. A. de Neuman, infra, p. 735. The requirement of budget balancing is a capitalist and not a socialist requirement. It has given rise to considerable controversy among economists favoring the marginal cost principle and those favoring the average cost principle. See Beacham, supra note 53, at 556-557. The average cost principle is now generally accepted.

6t This point is rightly stressed in Haldane, The Central Electricity Board and Other Electricity Authorities, in Public Enterprise, op. cit. sttpra note 13, at I49. The Companies Act, I948, II \& I2 Geo. 6 , c. $38, \S 19$ provides that a company which by its articles prohibits the distribution of profits and serves a general useful object, might be granted dispensation with the requirement of embodying the word "Limited" in the corporate name.

${ }^{o r}$ In Greenhalgh v. Arderne Cinemas, Ltd., [1950] 2 All E. R. I120, I126.
} 
In labor relations, the corporations are employers; labor disputes arise between them and their employees in the same manner as between a private employer and his men. They negotiate with the trade unions representing the men, and infinite patience is required to establish satisfactory conciliation, negotiation, and consultation machinery on all levels; but, as Mr. W. Kenneth Gratwick points out, ${ }^{\text {60 }}$ mutual confidence and the will to cooperate is more important in labor relations than machinery for the settlement of disputes; in that respect, as in their attitude to profit, the corporations bear a responsibility to the nation.

In the result, the quasi-autonomous character of the public business corporation creates tensions. That, in itself, is no misfortune. Tensions exist in every corporate body; in fact, the corporate organization is often a convenient vehicle to lessen social tensions. In the company, for instance, the managerial and the proprietary interest, the majority and the minority, equity, preference share and loan capital might sometimes conflict. The important question is whether, in the end, the organization can accommodate the different interests or whether the friction resulting from those tensions will break the organization. In that respect, the public business corporation is still in the experimental stage. The principal source of strain is its strange dualism of commercial independence and political control; secondary sources of tension which sometimes are apparent, are conflicts of the managerial interest of the corporations with the interests of their consumers and employees. As regards the principal centrifugal forces, the tendency is at present to emphasize the business character of the corporations. That is due to three causes: it stresses the historical continuation, it is escapism from political controversy into the practical world of achievement, and it contributes to the integration of the new type of organization into the national economy which is founded on private enterprise. From the constitutional point of view, the clear recognition of the business character of the public corporation owning and managing a nationalized industry is probably the most formidable gain of the law of nationalized industries during the past five years, but that position appears now to be consolidated. At present, the true difficulty is on the other end of the scale: it concerns the delimitation of the managerial functions of the corporation from Parliamentary and ministerial control. Mr. Charles Winter, who examines these problems, ${ }^{67}$ discusses the constitutional conventions and administrative precedents which begin to emerge; the indirect control of Parliament over the corporations is taking form and shape, but how gradual that process is might be gathered from 'the fact that only at the end of 1950 the government conceded the im. portant principle that the activities of public corporations should be reviewed by a committee, including a limited number of members of Parliament, at regular intervals of five or seven years in a manner similar to that applied to the British Broadcasting Corporation when the renewal of its charter was under consideration.

${ }^{80}$ Injra, p. 652. The statutory machinery of negotiation and arbitration of labor disputes in nationalized industries is described by Turner-Samuels, Industrial Negotiation and Arditration, Part IV (ig5i).

${ }^{\circ}$ Infra, p. 670 . 
The even more important problem of direct contacts between the parent minister and the board of the corporation is, as far as the public is concerned, still shrouded in mystery. It cannot, therefore, be said how far the definition of the spheres of ministerial policy-making and corporate management of affairs has progressed. It might be recalled that that delimitation caused considerable difficulty in the Tennessee Valley Authority; in the first years the three members of the board discharged both kinds of functions, and only in 1937 the two functions were separated and the management and administration entrusted to a general manager while policy making remained the sole concern of the board. ${ }^{68}$ As in practice the functions of policy making and management overlap, the relationship of the corporation to the parent minister is the most sensitive and, perhaps, the weakest part of its constitution. The ultimate fate of the public business corporation depends on its ability to establish an equilibrium between ministerial influence and managerial independence.

Compared with this fundamental problem, the reorganization of public business corporations in the light of experience gained during their work is of secondarythough not negligible-character. The public corporation, like a form of private enterprise, has to adapt its constitution to changing circumstances and demands. Thus, in 1949 it was thought expedient to divide the Road Transport Executive originally created by the Transport Act, I947, into two Executives, viz., the Road Haulage Executive and the Road Passenger Executive, ${ }^{68^{a}}$ and at present the question of decentralization of the National Coal Board is much discussed..$^{6{ }^{b}}$

\section{IV}

\section{Nationalization and Private EnTERPRise}

The nationalization of basic industries had considerable repercussions on the economic behavior and legal structure of industrial and commercial undertakings which continued to remain in private ownership. In particular, it clarified the attitude of English law to the problem of private monopoly and indirectly influenced the reform of company law.

As regards the former, the address of $\mathrm{Mr}$. Herbert Morrison which was referred to earlier, ${ }^{69}$ makes it clear that the labor government did not adopt the demand of socialist theorists that a private monopoly enterprise was invariably ripe for nationalization. The passing of the Monopolies and Restrictive Practices (Inquiry and Control) Act, $1948,{ }^{70}$ gave formal recognition to that view because the Act provides pro-

os C. Herman Pritchett, The Tennessee Valley Authority 153 -165 (1943).

aga British Transport Comisission (Executives) (No. 2) Order, I949 (S. R. 1949, No. II30).

asb See C. G. Lancaster, M.P., (with Str Charles Reid and Sir Eric Young), Structure and Control of THE COAL INDUSTRY (I95I). The authors of this pamphlet which is published by the Conservative Political Centre, recognize that public ownership in the industry has come to stay and argue in favor of a measure of regional decentralization.

${ }^{\text {"o }}$ See nate 58 supra.

${ }^{70} 11$ \& 12 Geo. 6, c. 66; see Ivamy, The Control of Monopolies, 17 Sor. 153 (1950); Further Developments in Resale Price Maintenance and Monopoly Control, 18 SoL. 55 (195r). 
cedures for the investigation into private monopoly enterprises and for their control if they operate against the public interest.

It is well known that in matters of monopoly and trade restraint American law is fundamentally different from English law. ${ }^{71}$ The attitude of the English courts to private monopoly and trade restraint may be gathered from the observations of Lord Parker in Attorney General of the Commonwealth of Australia v. Adelaide Steamship Co., ${ }^{72}$ a Privy Council case dealing with the Australian antitrust legislation, and of Asquith, L. J., in Monkland v. Jack Barclay, Ltd. ${ }^{\mathbf{7 3}}$ In the former case, Lord Parker who delivered the opinion of the board, reviewed the attitude of the common law in a passage which has become the locus classicus of the subject: ${ }^{74}$

... a contract in restraint of trade, though reasonable in the interests of the parties, may be unreasonable in the interests of the public if calculated to produce that state of things which is referred to by Lindley and Bowen, LJJ., ${ }^{75}$ as a pernicious monopoly, that is to say, a monopoly calculated to enhance prices to an unreasonable extent. ... The onus of shewing that any contract is calculated to produce a monopoly ... . will lie on the party alleging it and ... if once the Court is satisfied that the restraint is reasonable as between the parties this onus will be no light one.

In Monkland v. Jack Barclay, Ltd., the "covenant system" of the British Motor Trade Association was discussed. The supply of new cars to buyers in Britain falls short of the demand in consequence of the requirements of the export trade, and a buyer has to sign a covenant whereby he undertakes not to re-sell the car within twelve months after its delivery. ${ }^{76}$ All car manufactures adhere to the scheme and are obliged to stop the supply of cars to dealers who sell new cars without obtaining the customer's signature to the covenant. The covenant scheme, which is a voluntary trade arrangement, is obviously strongly restrictive in character. In the case before the court, a buyer bought a car (but did not obtain delivery) before the scheme was extended to cars of the particular manufacture in question and his contract did not contain a covenant against re-sale; later, the system was extended and the dealer requested the buyer to sign the covenant; on the buyer's refusal he appropriated the car to the next customer on his waiting list. The buyer sued for damages, but the court dismissed the action and the Court of Appeal affirmed that decision for reasons connected with the construction of the contract in issue. In the course of the argument in the Court of Appeal, counsel for the dealer submitted that the maintenance of the covenant system was so important that a delivery of a car to a cus.

\footnotetext{
${ }^{71}$ For discussions of these differences, see: Meier, A Critique of the New British Monopoly Act, 48 Mich. L. Rev. 329 (1950); Note, The British Monopolies Act of 1948: A Contrast with American Policy and Practice, 59 YALE L. J. 899 (1950).

${ }^{72}$ [1913] A. C. 781 .

73 [195I] x All E. R. 716.

7s Attorney General of the Commonwealth of Australia v. Adelaide Steamship Co., Ltd., stipra note 72 , at $796-797$.

${ }^{75}$ In Maxim Nordenfelt Guns and Ammunition Co. v. Nordenfelt, [1893] I Ch. 630, 668, affd, [1894] A.C. 535 .

${ }_{70}$ The time has now been extended to two years.
} 
tomer who refused to sign it was contrary to public policy! This argument in favour of a "good" restraint was rejected by Asquith, L. J., who delivered the judgment of the court, obiter, as savoring of paradox: $:^{77}$

The policy of the law still leans towards free trade.... The merits of the covenant scheme and the alleged disadvantages of not enforcing it do not seem to us in the least incontestable. ... It was suggested by counsel for the defendants that the Motor Trade Association's covenant scheme had the approval of the government or of government officials and that this was in some way relevant to the question whether a contract which departed from it was or was not contrary to public policy.... . We think that this is an unfounded suggestion. What one government approves its predecessor or successor may condemn, and, if the suggestion were acted on, precisely the same contract might have to be held void when government $A$ was in and valid when government $B$ was in power. The distinction between political policy and public policy was firmly drawn in Egerton v. Brownlow. ${ }^{78}$

It is not surprising that the Act of I948, carried through Parliament by a government which itself created large monopolistic enterprises of public character, continued the policy of the law to differentiate between harmless monopolies and those conflicting with the public interest. The Act exempts from its purview monopolies in favor of the nationalized industries by providing that no reference under it can be made where the monopoly is expressly authorized by Act of Parliament $\left(\$ 2(\mathrm{I})\right.$, proviso) $;^{79}$ it thus applies only to conditions constituting a private monopoly which might exist as regards the supply, the processing, and the export of any goods, including buildings and structures, ships, and aircraft ( $2(\mathrm{I})$; $20(\mathrm{I})$ ). Monopolistic or restrictive conditions are present where

(a) at least one-third of all the goods in question or any substantial part thereof are supplied by or to one person, or by or to two or more persons who are an inter-connected group of companies within the Companies Act, I948, Section I54, or who conduct their affairs by formal arrangement or otherwise in such a manner as to prevent or restrict competition; or

(b) no goods of the kind in question are supplied in the United Kingdom or any substantial part thereof as the result of any agreement or arrangement, whether legally enforceable or not $(\$ \$ 3-5)$.

A Monopolies and Restrictive Practices Commission is set up which consists of not less than four and not more than ten members appointed by the Board of Trade ( $(\mathrm{I})$; the present chairman is Sir Archibald Carter. The Board of Trade has power to refer matters to the Commission, and two types of references are provided: the limited reference which requires the Commission to investigate and report on facts, and the full reference which requires it, in addition, to report whether the alleged

\footnotetext{
${ }_{77}$ Monkland v. Jack Barclay, Ltd., supra note 73, at 723.

${ }^{78}{ }_{4}$ H. L. Cas. I (1855).

70 This does not apply to monopolies based on patents or trade-marks.
} 
monopolistic or restrictive conditions operate, or may be expected to operate, against the public interest $(\$ 6)$. The reports of the Commission are normally laid before Parliament and published ( $\$ 9)$. Where, on a full reference, the Commission finds that monopolistic or restrictive conditions operate or are likely to operate against the public interest, or the House of Commons resolves so, the minister concerned may take remedial or preventive action; this is done by an order which has to be approved by each House of Parliament and which may declare unlawful the agreement or arrangement in question or make other provisions (\$ro(2)). The order can be enforced by injunction or other civil proceedings by the Crown, and the making of the order does not limit the right of any other person to bring civil proceedings, but no criminal proceedings lie for a contravention of the order (\$II). So far, eight references have been made to the Commission ${ }^{80}$ and one report, viz., on dental goods, has been published; ${ }^{81}$ this report, made on a full reference, stated that monopolistic conditions were present and that certain rules of the trade association of dental manufacturers and traders operated against the public interest, but the Commission added that no great abuse of powers had actually taken place; the Minister of Health who is the competent authority to act in that instance, has not yet made an order. The Monopolies Act of 1948 has not had a profound effect on private monopolistic enterprise in Great Britain; in particular, it did not enable the government to deal effectively with the practice of re-sale price maintenance which prevents shopkeepers from reducing prices laid down by the manufacturer or other supplier. In June, I95I, it was announced that the government intended to introduce legislation to make illegal

(I) collective arrangements designed to ensure that goods shall be sold at or above specified retail prices,

(2) any indication by a manufacturer or other supplier of goods of a re-sale price for those goods unless that price is clearly stated to be a maximum price. ${ }^{81 *}$

The influence of the nationalization acts on company law, was, it is believed, greater than is commonly realized. Though there is no provision in the Companies Act, $1948,{ }^{82}$ which refers to the nationalization legislation, the new company law grew up in the shadow of nationalization. The Committee on Company Law Amendment, whose chairman was the present Lord Justice Cohen, was appointed

${ }^{80}$ They concern: (I) electrical lamps, (2) insulated electric wires and cables, (3) rain water goods, etc., and miscellaneous builders' goods, (4) dental goods, (5) machinery for manufacture of matches, (6) matches, (7) certain copper and copper alloy goods, and (8) supply of insulin. (Position as on Mar. 28, I95I).

S1 Report on the Supply of Dental Goods (H. M. S. O., T950).

${ }^{81 a}$ A Statement on Resale Price Maintenance Presented by the Bodrd of Trade to Parliament. Card. No. 8274 .

${ }^{82}$ This Act is referred to in the text. The actual reform was carried out by the Companies Act, 1947, I0 \& II GEo. 6, c. 47, which when later consolidated with the Companies Act, 1929, I9 \& 20 GEo. 5, c. 23 , into the Act of 1948 , II \& 12 GEo. 6 , c. 38 , was repealed, with the exception of a few insignificant provisions affecting other enactments. See also: Murphy, $A$ Revision of British Company Laty, 30 MiNN. L. REv. 585 (1946); Notc, British Corporate Law Reform, 56 YALE L. J. 1383 (1947). 
in 1943, when the view was widely held that a limited measure of nationalization was unavoidable. The report of the Committee was published in $1945^{83}$ and was implemented by legislation which was before Parliament between $\mathrm{r} 946$ and $\mathrm{I} 94^{8}$ when most nationalization acts were enacted. The Company Law Reform was, in fact, a most effective and successful instrument of reorganization of private enterprise in the face of actual or threatened nationalization. ${ }^{84}$ That is, in particular, true of the law of public companies and groups of companies. The provisions dealing with public accountability were greatly extended and the public character of the public company is strongly emphasized. The Act of 1948 requires group accounts for inter-connected companies ( $\$ \$ 150-154)$, the auditor is given a professional standing $(\$ 161)^{85}$ and independence of status $(\$ 162)$, the rights of the minority are strengthened (\$2ro), the Board of Trade are given extensive powers of investigation ( $\$ \$ 164-175)$, and even an age limit is introduced for directors $(\$ 185)$ !

In the result, the higher forms of private enterprise, while fully maintaining the vital difference in the matter of ownership, have accepted public control of their corporate life to a degree hitherto unknown. This development is complementary to the tendency of the nationalized industries to emphasize their business character. As the result of that alignment the structural unity of industrial organization in Great Britain has been maintained.

${ }^{83} 4$ Parliamentary Parers, 1944-1945, pt. r. CMd. No. 6659.

84 The furure evolution of the joint stock company is discussed in GeORGE GOYDER, THE Future or Private Enterprise (195I), and in Austen Albu, M.P., and Norasan Hewett, The Anatomy op Pruvate IndustRy (195I).

${ }^{85}$ Cf. the dissenting opinion of Denning, L. J., in Candler v. Crane Christmas \& Co., [195I] I All E.R. 426,428 . 